\title{
Medical genetics: end of the beginning or beginning of the end?
}

\author{
Reed E. Pyeritz, $M D, P h D$
}

Interest in the human aspects of genetics is at an all-time high. Rarely does a week pass when the national media fail to report that a gene has been associated with, or a chromosomal region linked to a human phenotype. The American Medical Association (AMA) recently sponsored a course expressly to educate primary care providers about genetics issues relevant to their practices. The Vice-President of the United States was the featured speaker at an event sponsored by the Genome Action Coalition and was given the James Watson Award. Vice-President Gore chose the occasion to announce that the Administration would sponsor legislation to prohibit discrimination in the workplace based on genetic information. President Clinton, in his State of the Union Address, said:

Think about this-the entire store of human knowledge now doubles every 5 years. In the 1980 s, scientists identified the gene causing cystic fibrosis-it took 9 years. Last year, scientists located the (sic) gene that causes Parkinson's disease-in only 9 days. Within a decade, "gene chips" will offer a road map for prevention of illnesses throughout a lifetime.... We have already discovered genes for breast cancer and diabetes. I ask you to support this initiative so ours will be the generation that finally wins the war against cancer, and begins a revolution in our fight against all deadly diseases. ${ }^{1}$

I, for one, never thought I would see the day that the President of the United States would bring such national attention to my discipline, and so overtly rally not just legislative, but national support for the work I love.

The President went on to say, "As important as all this scientific progress is, we must continue to see that science serves humanity, not the other way around. We must prevent the misuse of genetic tests to discriminate against any Americans." To achieve this, the Administration and many members of Congress are supporting legislation to extend the protections begun by the Kassebaum-Kennedy bill of 1997 by prohibiting discrimination in health insurance based on genotype. The American College of Medical Genetics (ACMG) has endorsed such legislation.

These should be days of high expectation, extraordinary activity, full employment, and strong interest by young health care professionals entering the field of medical genetics. I do not want to burst this bubble. However, although "genetics" flourishes, I am very concerned about the future of the profession of medical genetics. There are warning signs.

\section{After the genome project}

More and more often, educated people ask me what I am going to do when the Genome Project is finished. I am actually much more worried about what I am going to do when managed care penetration reaches $80 \%$, but more about that later. Although we all know that the implication that geneticists will have nothing more to learn is patently naive,

Departments of Human Genetics, Medicine and Pediatrics

Allegheny University of the Health Sciences

Pittshurgh and Philadelphia, PA

Presented at the Annual Meeting, Los Angeles, March 1998 we must be aware of perception as well as reality. We need to worry that some people think the field of genetics will end in 2005, or sooner, if the US, international, or private Human Genome Projects continue at their current pace.

\section{The future of education in medical genetics}

Traditionally, medical geneticists, trained as $\mathrm{PhD}$-certified laboratory directors, MS-certified genetic counselors, MD-certified clinical geneticists, or a combination thereof, have functioned in education, clinical service, and research. One can certainly argue persuasively that the era of the "triple threat" has passed, but even the professional who is productive in one or two of these areas is encountering problems. These will be elaborated subsequently. In education, genetics is seemingly riding ascendant, but close inspection shows some signs of distress.

- Medical curricula are becoming "integrated" and "problem-based," which may be good pedagogy, but eliminates distinct courses in genetics.

- Graduate programs are becoming increasingly multidisciplinary, with "human genetics" subsumed by molecular biology or molecular medicine.

- In postdoctoral education, we see an increase in multiple sequential postdoctoral positions. In some scientific disciplines, this is due to a lack of entry level jobs. In human and medical genetics, the reasons are related less clearly to a paucity of jobs, than to the higher demands made by the employers on new hires.

- In place of what we used to call "fellowships," we now have residencies, affirmed by our own Residency Review Committee of the Accreditation Council for Graduate Medical Education for the past few years. However, the number of programs has contracted to about 50 , or less than half of what existed 10 years ago, and many accredited programs have a dirth of qualified applicants.

\section{Organized medicine sees the importance of medical genetics}

Why is this a warning sign? Should we not be delighted that the AMA and medical specialty societies are asking for help in teaching practicing physicians about genetics? We need to recognize this as a doubleedged sword. When we participate in educating our colleagues without seeming self-serving, we also prepare them to deal with much of the routine clinical work for which we have been reimbursed. Even with increased referrals for consultation, we will be spending increased time on truly difficult cases for which reimbursement does not begin to cover our costs. I am in awe of my colleagues in the Association of Professors of Human and Medical Genetics, the National Coalition for Health Professional Education in Genetics, and the ACMG who are truly devoted to spreading the gospel of medical genetics. But we cannot give away all of our secrets!

I propose we take a systematic look at how we got to where we are today.

\section{From where we came}

Both our intellectual forefathers and our progenitor role models deserve mention. Our intellectual forefathers predate anyone at this 
meeting and include Gregor Mendel, Francis Galton, William Bateson, and Archibald Garrod. These individuals deserve to be understood by the geneticists of today for the personalities they were, and for the astonishing insights they presented, often to an uncomprehending world. Particularly appropriate to emphasize the relationship of Bateson with Garrod: the pure scientist providing the insight for a pure clinician to deduce the timeless relationship of the chemical individuality of humans.

The field of medical genetics has emanated from the pure science of human genetics. The American Society of Human Genetics (ASHG) spawned the ACMG. In this we are distinct from our medical peer group; typically the practice society (academy or college) originated with the practicing professionals, whereas the research societies developed as offshoots of the colleges and academies or independently.

Our progenitor role models are the pioneers of medical genetics and dysmorphology: Barton Childs, James Crow, F. Clarke Fraser, Robert Gorlin, Kurt Hirschhorn, Victor McKusick, Arno Motulsky, James Neel, John Opitz, Charles Scriver, David Smith, and Josef Warkany. These individuals were the most prominent driving forces behind the development of the major themes in medical genetics during its first halfcentury (Table 1). Few if any fields of medicine or science have witnessed such a profound and rapid evolution. ${ }^{2}$ No matter when an individual entered the field of medical genetics during the past 40 years, he or she would have had to undergo near-constant continuing education and practice modification. By the late 1970s, the nature of medicine in general and the explosion of information and techniques in medical genet-

Table 1

Time line of major developments in medical genetics

\begin{tabular}{|c|c|}
\hline 1950s & $\begin{array}{l}\text { Clinical genetics } \\
\text { Mathematical genetics }\end{array}$ \\
\hline $1960 \mathrm{~s}$ & $\begin{array}{l}\text { Cytogenetics } \\
\text { Biochemical genetics } \\
\text { Genetic nosology } \\
\text { Dysmorphology }\end{array}$ \\
\hline 1970s & $\begin{array}{l}\text { Prenatal diagnosis } \\
\text { Genetic counseling } \\
\text { Molecular diagnosis }\end{array}$ \\
\hline $1980 \mathrm{~s}$ & $\begin{array}{l}\text { Genomics } \\
\text { Biotechnology } \\
\text { De-academization of genetic services }\end{array}$ \\
\hline 1990s & $\begin{array}{l}\text { Genetic informatics } \\
\text { Genetics of complex disease } \\
\text { Molecular medicine } \\
\text { Consumerization }\end{array}$ \\
\hline $2000 \mathrm{~s}$ & $\begin{array}{l}\text { Pathogenetics \& functional genomics } \\
\text { Gene therapy for hereditary disorders } \\
\text { Ecogenetics } \\
\text { Public health }\end{array}$ \\
\hline
\end{tabular}

Table 2

Diplomats of the American Board of Medical Genetics and the American Board of Genetic Counseling

\begin{tabular}{lrrrrrrr}
\hline Speciality & 1982 & 1984 & 1987 & 1990 & 1993 & 1996 & Total \\
\hline Clinical & 283 & 128 & 113 & 134 & 136 & 123 & 917 \\
Cytogenetics & 123 & 79 & 103 & 61 & 61 & 64 & 491 \\
Biochemical & 57 & 26 & 25 & & 29 & 22 & 159 \\
Molecular & & & & & 144 & 83 & 227 \\
Biochemical/molecular & & & & & 47 & 2 & 49 \\
PhD medicalgenetics & 56 & 30 & 27 & 12 & 12 & 10 & 147 \\
Genetic counseling & 167 & 144 & 179 & 141 & $181^{a}$ & $258^{a}$ & 1070 \\
Total diplomas & & & & & & & 3060 \\
Total people certified & & & & & & & 2741 \\
\hline
\end{tabular}

${ }^{a}$ In these years, genetic counselors were certified by the American Board of Genetic Counseling

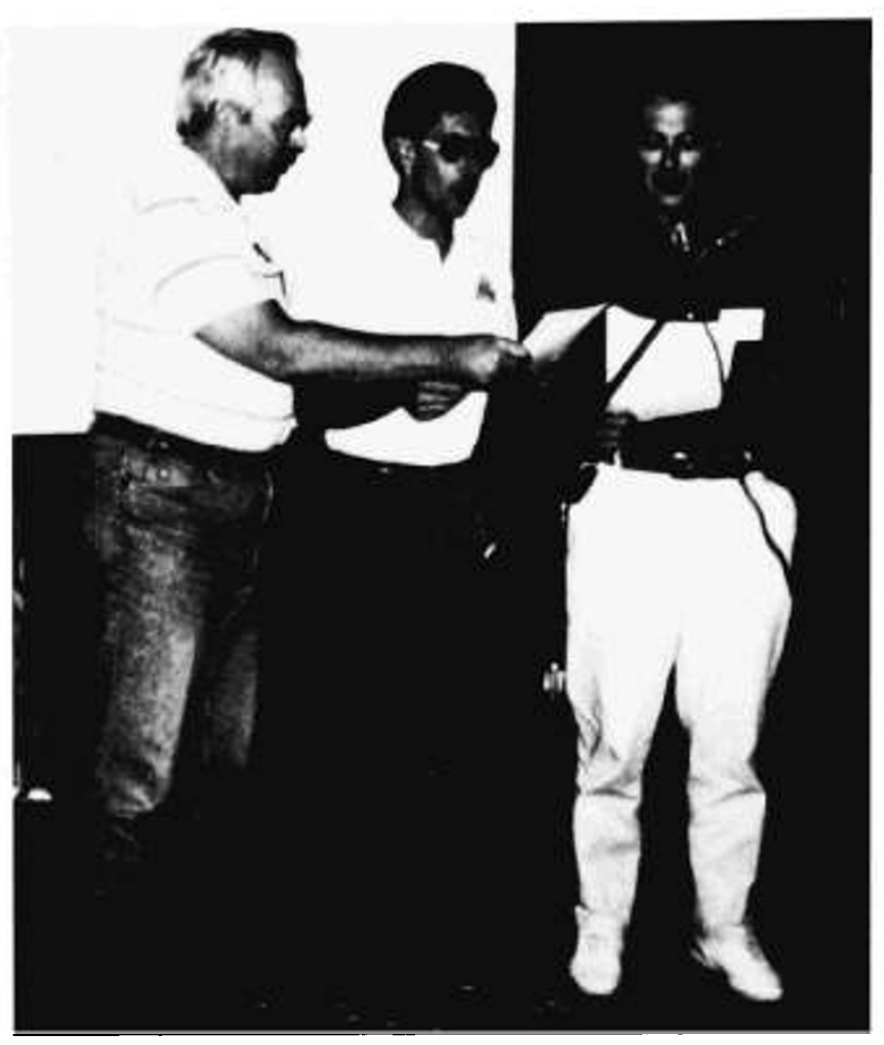

FI. 1 Selling the notion of the College. Jim Hanson, Reed Pyeritz, and Dave Rimoin "present" at the David W. Smith Workshop on Malformations and Morphogenesis, Lake Arrowhead, California, September, 1991.

ics resulted in a promotion of specialization and a concomitant requirement for quality assurance.

The American Board of Medical Genetics (ABMG) was incorporated in 1980 and administered its first examinations in 1981. Since then, 3060 diplomas have been awarded to 2741 individuals (Table 2). The ABMG was recognized by the American Board of Medical Specialties in 1991, a crucial step in the development of the ACMG but at the cost of having to form a separate American Board of Genetic Counseling to certify our genetic counselor colleagues.

The ACMG was conceived by a small group of ASHG members in 1989 , and a steering committee worked for a couple of years to produce bylaws. Just as some had resisted the notion of certification and "specialization" of our discipline, more than a few medical geneticists saw no need for a College. Those of us on the steering committee had to take our lobbying on the road to win support. In Figure 1, Jim Hanson, Dave Rimoin, and yours truly are trying, in song, to sell the attendees of the annual David Smith Workshop on the merits of a College. Talk about a tough audience!

On 14 September, 1991, at a modest hotel in Santa Monica, CA, the bylaws were approved and the ACMG was incorporated, with the steering committee becoming the first Board of Directors (Fig. 2) and David Rimoin anointed first President.

From the beginning, the ACMG had membership in the AMA House of Delegates and American Board of Medical Specialties recognition of the discipline of medical genetics as its goals. But the College was virtually unique among professional societies that had an eye on becoming members of the medical establishment by granting $\mathrm{PhD}$-certified medical geneticists status as full Fellows. Only the American Board of Nuclear Medicine grants such status to nonphysicians.

The first Fellows were admitted in 1993. The first College elections were held in 1994, with David Rimoin chosen as first elected President.

\section{Where we are}

The ACMG is now $65 / 12$ years old; clearly out of infancy, but still a child-a precocious child, perhaps, but with a lot of maturation ahead. 


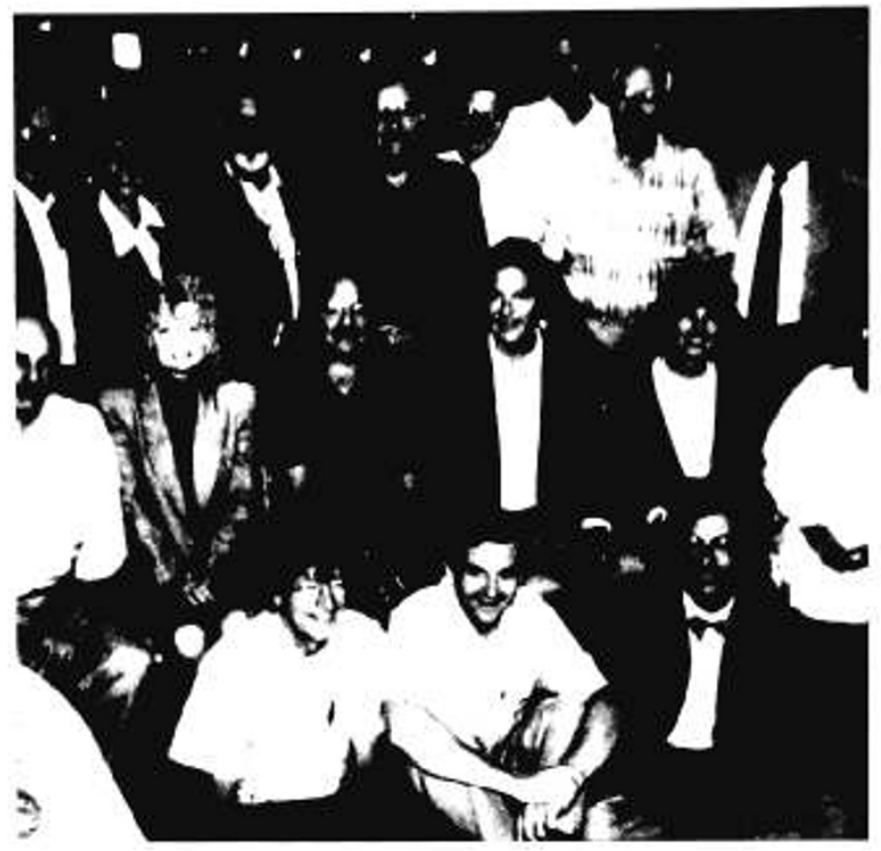

Fis 2 The Founding Committee of the American College of Medical Genetics, at the incorporation, 14 September 1991, Santa Monica, California. Front row: Laird Jackson, Art Beaudet, Reed Pyeritz; middle row: Steve Goodman, Pat Murphy, Maimon Cohen, Dave Rimoin, Jessie Davis, Elaine Strass (ASHG Executive Director); back row: Bob Greenstein, Lynn Fleisher, Mike Kaback, Rod Howell, Sherm Elias, Mike Watson, Jim Hanson, Kurt Hirshhorn.

Our membership (Table 3 ) represents about two-thirds of all ABMGcertified $\mathrm{MD}$ and $\mathrm{PhD}$ medical geneticists who are currently practicing, a relatively high percentage for specialty societies. The annual meeting of the College, presented in conjunction with the March of Dimes Birth Defects Foundation Clinical Genetics Conference, focuses on continuing education, clinical research, and the business of the committees of the College. The decreases in attendance and abstract submission for the 1998 meeting are disconcerting and will be studied carefully by the ACMG leadership (Table 4). We recognize that virtually everyone in health professions in the United States and Canada these days has more demands on their time and fewer discretionary dollars to spend on meetings. Nonetheless, the ACMG annual meeting must become so valuable that no member would think of missing it and medical geneticists from around the world will be interested in attending.

In a modest reference work, Victor McKusick stated in his excellent chapter, 'The History of Medical Genetics:' "Since 1956 Medical Genetics has become medicalized, subspecialized, and professionalized. More recently, it has become molecularized, commercialized, democratized, universalized, and consumerized." ${ }^{3}$ Against this background of evolution, it is a cliché to say that we are in the midst of two major revolutions: the first involving genetics as the point discipline for biomedical science; the second involving the structure of health care. These may be clichés,

Table 3

Membership of the American College of Medical Genetics ${ }^{a}$

Fellow, $\mathrm{PhD}$

Fellow, MD, AMA

Fellow, MD

Fellow, MD, Canadian

Associate

Other categories

Total membership
Table 4

Annual meetings of the American College of Medical Genetics

\begin{tabular}{llccccc}
\hline & & \multicolumn{4}{c}{ Attendance } & \\
\cline { 2 - 5 } Year & Site & Total & PhD & MD & Counselor & Abstracts \\
\hline 1994 & Orlando & 579 & 108 & 194 & 56 & 166 \\
1995 & Los Angeles & 642 & 101 & 335 & 156 & 214 \\
1996 & San Antonio & 575 & 100 & 335 & 105 & 197 \\
1997 & Ft. Lauderdale & 610 & 100 & 321 & 182 & 183 \\
1998 & Los Angeles & 519 & 136 & 212 & 113 & 148 \\
\hline
\end{tabular}

but every Dean in my acquaintance complains that the latter revolution is in danger of stifling the former. Managed care is the order of the day; if your area has not been "penetrated," it will be. The majority of health maintenance organizations are for-profit, and currently enroll $62 \%$ of managed care lives. ${ }^{4}$ The organization, financing, incentives, and practice, if not the philosophy, of open-panel managed care plans leave little room for medical genetics. Clinical genetic laboratory services are provided by the low bidder, with scant regard for quality and no regard for perpetuating training environments for our successors. ${ }^{5}$ With the high turnover of patients and families among managed care plans, neither not-for-profit nor for-profit plans have strong incentive for practicing true preventive health that spans generations. ${ }^{6}$

We continue to struggle under the perception of many that reproductive genetic services equate to pregnancy termination.

In the absence of state or federal protection, people with a perceived or actual risk of any disorder can be excluded from a plan, perhaps under the guise of a "preexisting condition," or the specific genetic susceptibility can remain uncovered by the plan.

The primary care physicians, who usually act as the "gate-keepers" for access to specialized services, have a financial disincentive to refer patients and relatives to consultants, such as medical geneticists. So we come back to the conundrum noted above in connection with education of primary care physicians: card-carrying medical geneticists are in danger of being marginalized in the present health care environment. When primary care physicians know little about medical genetics, patients and their families suffer, and medical geneticists do not get involved at all, or until its too late. However, the more primary care physicians know about the rudiments of medical genetics, the more they become competent to perform many of the routine tasks currently done by medical geneticists, tasks that are reimbursed and that are not too timeintensive or cognitively challenging; this leaves only the really difficult, time-consuming, and poorly reimbursed tasks for the person certified as a medical geneticist. The very cogent argument has been made numerous times, again in the absence of hard data, that far too few cardcarrying medical geneticists and genetic counselors exist in the United States to deal with the burgeoning potential of genetics in medicine. These are issues that demand careful study and deliberate actions. I am reminded of the clinical geneticist who won the state lottery. When asked how she would spend the one-million dollars, she replied, "I guess I'll just keep doing clinical genetics until the money is gone."

\section{Where we are headed}

Are we at the beginning of the end of medical genetics? Or if not the end, then the beginning of, at best, a plateau? The leadership of the various genetics societies has a distinct sense that whatever is happening is out of their hands. In one attempt to gain some control, the ASHG, the Association of Professors of Human and Medical Genetics, the National Society of Genetic Counselors and the ACMG have contemplated embarking on an assessment of the human and medical genetic workforces. But the completion of any study is several years hence.

Because clear threats to our profession currently exist, I would argue that all require concerted action soon. Some of these threats include:

- What is medical genetics? If we paint with too broad a brush, then human cloning, reproductive technologies of all types, gene therapy, and even xenotransplantation get laid on our doorstep. How- 
ever, if we paint with too narrow a brush, the field risks becoming superspecialized and marginalized. Traditionally, most of us have been episodic, diagnostic consultants. We need to participate more fully in the longitudinal spectrum of diagnosis and treatment. ${ }^{7}$

- Health professionals involved in molecular medicine or hereditary disorders are viewed as "geneticists" by the lay public and often by physicians and administrators. Potentially, this will lead to diminished expectations for what a geneticist needs to provide and depreciation of board certification. The American Medical Accreditation Program of the AMA, although designed with the best of intentions, also risks a de-emphasis of the value of traditional board certification.

- Health professionals involved in molecular medicine or hereditary disorders often view themselves as geneticists. Occasionally this is overt and it constitutes hubris. Often it is subtle and unintentional. In either event, it accentuates the problems just mentioned. These issues will become accentuated only as somatic gene therapy achieves a role in medicine. The vast majority of clinical trials currently underway involve common diseases (cancer, coronary artery disease, HIV infection) and not mendelian disorders. As a result, a cadre of "gene therapists," often ordained as such by industry and academic institutions, will gain access to mainstream medicine. Few of them will be medical geneticists.

- Patient/consumer protection, autonomy, and confidentiality. Until these issues are addressed, in part by legislation, the full potential of medical genetics will not be realized. ${ }^{8}$

- Genetic determinism. We can never overlook the fear that the concepts of genetic manipulation (witness concern over engineered vegetables) and eugenics can engender. ${ }^{9}$ Furthermore, we all must be aware that economic issues will potentially drive application of genetic information and technologies.

- Nondirectedness of genetic counseling. The previous issue and the likely widespread participation of health professionals not schooled in the traditions of medical genetics in delivering genetic services likely will increase specific recommendations to consumers about genetic issues. Directed counseling potentially leads to cleaner outcomes research, and can serve the purposes of an insurer or health maintenance organization interested in targeting behavior.

- Great expectations. With the media attention on the Human Genome Project and the tendency for all health care professionals to read only headlines or skim abstracts, there is considerable anticipation about the power of genetic information. ${ }^{10}$ Occasionally, a colleague asks me to find a mutation in a patient with a rare disease, the gene for which was discovered last week. Frequently, I am asked to have our molecular diagnostic laboratory determine the apolipoprotein $\mathrm{E}$ genotype of a relative of a patient with Alzheimer's disease. ${ }^{1-13}$ Explaining the limitations of our technology, the expense involved, and the ethical and social issues lead invariably to a lengthy curbside consult (unreimbursed) and, at best, mild exasperation on the part of the consultant.

- The economic viability of medical genetic services. Although no systematic survey has been performed, the general consensus is that no full-service medical genetic service exists without subsidy anywhere in the United States. Even clinical genetic laboratories that used to operate with a considerable positive margin (primarily cytogenetics) are struggling under decreased reimbursement. The recent and substantial revision of laboratory CPT codes, engineered largely by the ACMG that works through the AMA, may provide relief for a time. We and others have documented how labor- and time-intensive clinical genetics services are. ${ }^{14-18}$ The medical establishment thus far has been highly resistant to revising CPT codes for clinical genetics and genetic counseling to reflect actual work units. Furthermore, no state licenses genetic counselors, so they are generally unable to be reimbursed directly for the services they render.

- The ACMG is a small society. We are by far the smallest member of the Council of Medical Specialty Societies. We only recently grew to a full-time staff of two people. Our entire budget is less than what most professional societies spend on receptions for legislative aids on Capitol Hill. And although our dues seem high, they are much less than virtually all other medical societies.
Ennui. Membership in most medical societies is dwindling. While our total membership is stable, only $21 \%$ and $17 \%$ of newly certified MDs and PhDs, respectively, applied to join the ACMG after the last cycle of examinations. We must retain the seasoned members and recruit the new.

\section{What we as a profession and as a college must do}

- We must decide what constitutes our turf and then defend it vigorously. Neither governmental agencies, politicians, the biotechnology industry, nor the insurance industry should be telling us what medical genetics ought to be like. However, we must avoid spending so much time justifying what we are doing that we do not have time to do what we are justifying.

- As a profession, we are in dire need of outcomes research to substantiate our vision of our specialty. ${ }^{19,20}$ Managed care organizations respond primarily to market forces rather than professional values. ${ }^{6}$ We need to be able to document to the marketplace that what we do has clear value. The higher goal is improving patient care; the baser goal is maintaining and preferably growing in our share of the health care market.

- We must decide how we will interact with our colleagues and then assume leadership in promoting effective, collegial interactions. We can begin today by capitalizing on the four principles of clinical genetics that still confound the uninitiated health professional: pleiotropism, variability, genetic heterogeneity, and the benefits of a detailed family history. ${ }^{21,22}$ Clearly, the new frontier of genetics is common disease. ${ }^{23}$ At the risk of sounding patronizing, our colleagues need assistance in understanding and applying the complexities of genetic diagnosis, susceptibility testing, and counseling to everyday practice within the confines of what is ethical and economically feasible. The ACMG already has taken an important lead in this area through clinical practice guidelines, ${ }^{11,12,25-27}$ and stating clearly when standards of practice have not been established. ${ }^{28}$ Finally, we also can work as a profession to emphasize how medical genetics can be a lead discipline in preventive medicine and public health. ${ }^{29-30}$ Sooner or later, our nation will come to its senses and put adequate resources into these endeavors. We can learn from our colleagues in other countries. ${ }^{31,32}$

- The ACMG must work with consumer groups, other professional organizations, and the federal legislature to guarantee protections for employment and health insurance for individuals identified as having a genetic condition or susceptibility. It is ironic that we should require legislation to honor our tradition of equal treatment under the law, when in fact we all will have any number of genetic susceptibilities.

- We must help educate our medical colleagues, the media, and policy makers that "the end" of the Human Genome Project is just the beginning of the real excitement possible in medical genetics.

\section{Conclusion}

Many presidential addresses of professional organizations begin or end by reviewing what the first President of the society said. I could not do that because David Rimoin was wise enough not to say anything for the record, proving that he lacks the masochism allele. I lack the hubris to expect that 30 or 40 years from now any President of the ACMG, if it still exists, will be interested in what I have said here today. But I am certain that what we medical geneticists do or not do during the next several years will have a profound effect on the future of our specialty. I do not want our intellectual children and grandchildren to look back and say, "Why didn't they do it right?"

\section{References}

1. White House: Office of the Press Secretary, 1998. http://www.pub.whitehouse.gov/urires/L2R?pdi://oma.eop.gov.us/1998/01/27/11.text.1.

2. Pyeritz RE. A revolution in medicine like no other. FASEB J 1992;6:2761-2766.

3. McKusick VA. History of medical genetics. In: Rimoin DL, Conner JM, Pyeritz RE, editors. Principles and Practice of Medical Genetics, 3rd ed. New York: Churchill Livingstone, 1997;1-30.

4. Market facts, February 1998. Menlo Park, CA: Henry J. Kaiser Family Foundation, 1998. 
5. Milunsky A. Threatened survival of academic-based genetic laboratory services. Am J Hum Genet 1992;50:643-645.

6. Kuttner R. Must good HMOs go bad? The commercialization of prepaid group health care. N Engl J Med 1998;338:1558-1563,1635-1639.

7. Jorgenson RJ. Paradigm shifts and medical genetics (letter). Am J Med Genet 1998;76:99-100.

8. Rothenberg K, Fuller B, Rothstein M, Duster T, Kahn MJE, Cunningham R et al Genetic information in the workplace: Legislative approaches and policy challenges. Science 1997;275:1755-1757.

9. Garver KL, Garver B. The Human Genome Project and eugenic concerns. Am J Hum Genet 1994;54:148-158.

10. Cantor $\mathrm{CR}$. How will the Human Genome Project improve our quality of life? Nat Biotechnol 1998;16:212-213.

11. American Society of Human Genetics and American College of Medical Genetics. Points to consider: Ethical, legal, and psychosocial implications of genetic testing in children and adolescents. Am J Hum Genet 1995;57:1233-1241.

12. American College of Medical Genetics, American Society of Human Genetics and Working Group on ApoE and Alzheimer Disease. Statement on use of apolipoprotein E testing for Alzheimer disease. JAMA 1995;274:1627-1629.

13. McConnell LM, Koenig BA, Greely HT, Raffin TA Genetic testing and Alzheimer disease: Has the time come? Alzheimer Disease Working Group of the Stanford Program in Genomics, Ethics and Society. Nat Med 1998;4:757-759.

14. Pyeritz RE, Tumpson JE, Bernhardt BA. The economics of clinical genetics services. I. Preview. Am J Hum Genet 1987;41:549-558.

15. Bernhardt BA, Weiner J, Foster EC, Tumpson JE, Pyeritz RE. The economics of clinical genetics services. II. Time analysis. Am J Hum Genet 1987;41:559-565.

16. Bernhardt BA, Pyeritz RE. The economics of clinical genetics services. III. Cognitive genetics services are not self-supporting. Am J Hum Genet 1989;44:288-293.

17. Bernhardt BA, Tumpson JE, Pyeritz RE. The economics of clinical genetics services. IV. The economic impact of clinical genetics patients to the academic hospital. Am J Hum Genet 1992;50:84-91.

18. Myers TL, Prouty LA. Consumer costs for genetic services. Am J Med Genet 1987;26:521-530.
19. Beech R, Rona RJ, Swan AV, Wilson OM, Madalia S. A methodology for simulating the impact of DNA-probe services on the outcomes of pregnancies. Int J Technol Assess Health Care 1992;8:539-545.

20. Holtzman NA, Murphy PD, Watson MS, Barr PA. Predictive genetic testing: From basic research to clinical practice. Science 1997;278:602-607.

21. Pyeritz RE. Pleiotropy revisited: Molecular explanations of a classic concept. Am J Med Genet 1989;34:124-134.

22. Pyeritz RE. Family history and genetic risk factors: Forward to the future (editorial). JAMA 1997;278:1284-1285.

23. King RA, Rotter JI, Motulsky AG. The genetic basis of common diseases. New York Oxford University Press, 1992.

24. Lifton RP. Molecular genetics of human blood pressure variation. Science 1996;272:676-680.

25. American Society of Human Genetics/American College of Medical Genetics Test and Technology Transfer Committee. Diagnostic testing for Prader-Willi and Angelman syndromes. Am J Hum Genet 1996;58:1085-1088.

26. American College of Medical Genetics. Genetic susceptibility to breast and ovarian cancer: Assessment, counseling, and testing guidelines. New York State Department of Health, 1998.

27. American College of Medical Genetics. The evaluation of the newborn with single or multiple congenital anomalies: A clinical guideline. New York State Department of Health, 1998.

28. Holmes LB, Pyeritz RE. Screening for cystic fibrosis (letter). JAMA 1998;279:1068-1069.

29. Khoury MJ. Relationship between medical genetics and public health: changing the paradigm of disease prevention and the definition of a genetic disease. Am J Med Genet 1997;71:289-291.

30. Khoury MJ. From genes to public health: The applications of genetic technology in disease prevention. Am J Public Health 1996;86:1717-1722.

31. Harper PS. Medical genetics in the UK and the National Health Service.J Med Genet 1998;35:441-442.

32. Harris R, Reid M. Medical genetic services in 31 countries: An overview. Eur J Hum Genet Suppl 1997;5:3-21. 